\title{
Cardiovascular repair with bone marrow-derived cells
}

\author{
Woan-Sang Kim", Sangho Lee", Young-sup Yoon \\ Division of Cardiology, Department of Medicine, Emory University School of Medicine, GA, USA
}

p-ISSN 2287-979X / e-ISSN 2288-0011

http://dx.doi.org/10.5045/br.2013.48.2.76

Blood Res 2013;48:76-86

Received on June 1, 2013

Revised on June 11, 2013

Accepted on June 13, 2013

"Woan-Sang Kim and Sangho Lee contributed equally to this work.

*This work was supported in part by NIH grants DP3DK094346, RC1GM092035; and NIH contract, HHSN268201000043C (Program of Excellence in Nanotechnology Award); Wallace H. Coulter Translational Research Grant; Pilot grant of

Emory-Georgia Tech Regenerative Medicine; NSF-EBICS (Emergent

Behaviors of Integrated Cellular Systems) grant, CBET-0939511, USA; and Stem Cell Research Center of the 21st Century Frontier Research Program grant SC4300, funded by the Ministry of Science and Technology, Republic of Korea.

\section{Correspondence to}

Young-sup Yoon, M.D., Ph.D.

Division of Cardiology, Department of Medicine, Emory University School of Medicine, 1639 Pierce Drive, WMRB 3309, Atlanta, GA 30322, USA

Tel: +1-404-727-8176

Fax: +1-404-727-3988

E-mail: yyoon5@emory.edu

(C) 2013 Korean Society of Hematology

\section{Abstract}

While bone marrow (BM)-derived cells have been comprehensively studied for their propitious pre-clinical results, clinical trials have shown controversial outcomes. Unlike previously acknowledged, more recent studies have now confirmed that humoral and paracrine effects are the key mechanisms for tissue regeneration and functional recovery, instead of transdifferentiation of BM-derived cells into cardiovascular tissues. The progression of the understanding of BM-derived cells has further led to exploring efficient methods to isolate and obtain, without mobilization, sufficient number of cell populations that would eventually have a higher therapeutic potential. As such, hematopoietic CD31 ${ }^{+}$ cells, prevalent in both bone marrow and peripheral blood, have been discovered, in recent studies, to have angiogenic and vasculogenic activities and to show strong potential for therapeutic neovascularization in ischemic tissues. This article will discuss recent advancement on BM-derived cell therapy and the implication of newly discovered CD31 ${ }^{+}$ cells.

Key Words Cell therapy, Cardiovascular repair, Bone marrow, Paracrine, CD31, Neovascularization

\section{INTRODUCTION}

Cardiovascular diseases are major morbidity and mortality in the industrialized countries. In the United States, ischemic cardiovascular diseases are the number one cause of death [1]. Although numerous pharmacological and surgical therapies have been developed, many of the patients still exhibit grave symptoms and continue to show increasing heart failure or advance critical limb ischemia and the need for hospi- talization [2-4]. Due to our limited therapeutic options, the demand for novel methods of treatment for ischemic cardiovascular diseases has been increasing. One of the major causes of ischemic cardiovascular diseases is atherosclerosis. This leads to the blocking of the blood vessels, which, in turn, needs a new vascular growth for the affected tissues to prevent or reverse disease progression. Endothelial cells are a major component of blood vessels and, thus, are essential for vascular growth; therefore, the treatment of ischemic cardiovascular diseases should primarily aim neovasculariz- 
ation through endothelial cells.

The notion of stem cells has attracted much attention due to their potential to develop new tissues. Although ethically controversial, embryonic stem cells (ESCs) have shown promising potential for tissue regeneration; therefore, ESCs have been extensively studied for cardiovascular regeneration in animal models for the past decade. On the contrary to their vast potential, ESCs trigger host immune response to allogeneic ESCs [5], have shown the risks of teratoma formation [6], and need to be ethically solved before clinical translation. Thus, induced pluripotent stem cells (iPSCs) have been discovered to circumvent such issues [7, 8]. iPSCs, however, still have many questions to answer regarding its benefits and impediments [9-13].

In addition, adult stem or progenitor cells have shown promising outlooks in treating cardiovascular diseases, especially bone marrow (BM)-derived cells. This discovery has led to a wider approach to cell therapy. BM-derived cells have shown regenerative effects in both preclinical studies and clinical trials. Because of their suggestive results, BM-derived cells have been widely investigated, particularly BM-derived mononuclear cells (MNCs), endothelial progenitor cells (EPCs), or mesenchymal stem cells (MSCs). BM-derived EPCs have displayed therapeutic potentials in myocardial and peripheral vascular ischemia in animal models [14-21] and positive results in a series of clinical trials using EPCs or similar BM cells to treat post-MI cardiac dysfunction and critical limb ischemia [22-34]. Contrarily, in other studies, BM-derived MNCs exhibited contradictory results in a similar subset of patients with myocardial ischemia [35-38]. As more clinical trials with MNCs, early EPCs, MSCs, and $\mathrm{CD} 34^{+}$cells are underway, more agreeable conclusion will be drawn in the near future.

Advances and expansions have been made involving therapeutic effects of BM-derived stem and progenitor cells. Formerly, transdifferentiation into vasculature and/or cardiomyocytes was thought to be the predominant mechanism responsible for cardiac regeneration or repair $[17,20,21$, 39-47]; however, recent studies exposed such notions were overestimated [48-50] and that humoral or paracrine effects are the main mechanisms. The humoral mechanism benefits regeneration or restoration of myocardium and peripheral vascular tissues by inducing neovascularization, protecting ongoing cell apoptosis and degeneration, and promoting regeneration of endothelial cells, cardiomyocytes, and smooth muscle cells through soluble factors or cell-to-cell contact [42, 51-58]. Numerous attempts to identify the soluble factors responsible for paracrine effects of MSCs led to discovering secreted frizzled related protein 2 (Sfrp2), an antagonist of Wnt signaling [59], which had a dose-dependent cytoprotective effect, with its concentrations up to $15 \mathrm{nM}$, in in vitro caspase activity assay. Additionally, in their follow-up study, the exogenous delivery of Sfrp2 to rat hearts, at therapeutic doses of $4 \mu \mathrm{g}$ per heart, improved cardiac function in experimental MI [60].

Furthermore, the search of effector cells, using their markers that are not specific only to stem or progenitor cells, has led to the discovery of $\mathrm{CD} 31^{+}$cells, representing a subpopulation of BM- and peripheral blood (PB)-derived MNCs. These $\mathrm{CD} 1^{+}$cells were discovered to have higher angiogenic and vasculogenic activities and efficient neovascularization in hindlimb ischemia $[61,62]$. Hence, based on this information, this review will cover the characteristics and possibilities of EPCs, BM-MNCs, and recently identified CD31 ${ }^{+}$cells.

\section{ENDOTHELIAL PROGENITOR CELL (EPC)}

Base on the idea that endothelial cells are major components in maintaining vascular homeostasis and in pathogenesis of a variety of diseases, endothelial cells have been explored and BM-derived circulating progenitor cells or angioblasts in human peripheral blood (hPB) have been discovered [63]. Because these cells had properties like endothelial cells (ECs) and could differentiate into ECs, BM-derived circulating progenitor cells were referred as EPCs. Based on the notion that BM-derived circulating progenitor cells contribute to blood vessel growth, Asahara and colleagues suggested the groundbreaking concept of postnatal vasculogenesis by showing that EPCs were incorporated into the vasculature in adult animals and formed new vessels in ischemic models [39]. In addition, the transplantation of EPCs was able to induce neovascularization and assist ischemic limb repair [14]. The concept of postnatal vasculogenesis has been widely accepted; however, due to the lack of specific markers and to diverse phenotypes, an accurate and precise identification of EPCs has not been confirmed, yet. In addition, the advance of technologies allowed the identifying of the role of EPCs in disease pathogenesis [64-67] besides a normal component of the formed elements of circulating blood [68].

\section{Early EPC}

Due to the lack of specific surface markers on EPCs, various $\mathrm{BM}$ cell fractions were short-term cultured in endothelial differentiation media to enrich EPCs. For example, CD133, which is displayed on immature hematopoietic stem cells (HSCs), was used for culture derivation of EPCs [69]. On the other hand, for therapeutic purposes, the total MNC population, which has been widely used to obtain EPCs, was short-term cultured for 4-7 days on vitronectin- or fibronectin-coated dishes and the attached, or adherent, cells were used as EPCs, though not all of the cells collected were considered EPCs [14, 39, 63, 70, 71]. These cells expressed endothelial-like characteristics by the uptake of acetylated low-density lipoproteins, the binding of lectins, the expression of several EC-specific proteins (VEGFR-2, Tie2, vascular endothelial [VE]-cadherin, von Willebrand factor, endothelial nitric oxide synthase [eNOS], and CD146), and a low proliferation rate. On the contrary, other studies have refuted the endothelial-like characteristics of EPCs because these cells also displayed monocyte/macrophage markers, such as CD45, CD11b, and CD11c [54, 72-74]. Recent studies 
have also, instead, referred these cells as angiogenic cells [74], for they contribute more to vessel formation through angiogenic effects rather than form ECs in vivo. EPCs are able to incorporate into the neovasculature and differentiate into ECs [20, 39, 63]. Also, Wang et al. [75] postulated that EPC containing cell population is inherently multipotent and may include smooth muscle progenitor cells. Additionally, other studies pointed that EPCs were able to differentiate into cardiomyocytes and smooth muscle cells in mouse [47] and rat [17, 21] models of MI; peripheral EPCs, mobilized by granulocyte-colony stimulating factor (G-CSF) administration and myocardial ischemia, have displayed cardiac-, muscle-, liver-, and neural-lineage markers [76, 77]. However, this evidence of extra-endothelial transdifferentiation is sporadic and not widely accepted after the original publications.

In one study, EPCs have been shown to transdifferentiate by fusing with cells of different lineage, such as newly formed cardiomyocytes in mice, administered with human EPCs, contained both human and mouse X-chromosomes [78]. However, only $3 \%$ of the ECs displayed any evidence of human-mouse cell fusion. In addition, most studies have shown little or no evidence of fusion between EPCs and cells of different lineages. In most recent studies, the transdifferentiation of EPCs has been shown to be possible but not prevalent.

Expression of certain factors and molecules, such as eNOS and inducible nitric oxide synthase (iNOS), which increase circulation by dilating capillaries [42], and pro-angiogenic and anti-apoptotic growth factors (i.e. hepatocyte growth factor [HGF], insulin-like growth factor 1 [IGF-1], and VEGF) [51], is one of the ways that EPCs contribute to tissue regeneration and preservation. The release of certain growth factors causes the recruitment of EPCs around the ischemic area [52] and, in turn, stimulates the cells to proliferate, migrate, and maintain the survival of EPCs and pre-existing mature endothelial cells [79].

In earlier studies, EPCs were often administered systematically; however, in recent studies, due to the low rate of retention, cells have been transplanted or injected directly onto the affected area. Transplantation of EPCs [14, 16, 20, 80,81 ] facilitated neovascularization in animal models of acute myocardial ischemia, and analogous effects in humans $[30,82,83]$.

\section{Late EPC}

Late EPCs, or endothelial colony-forming cells (ECFCs), were discovered from circulating MNCs that were collected after more than 2 weeks in conventional EPC culture. These cells may be cultured variably; however, they commonly have round morphology, fast cell proliferation rate, and express similar surface markers (EC makers) [73, 84]. ECFCs need to be studied much further and their culture systems developed more before any application to therapeutic or regenerative use, because they were able to neither convincingly show paracrine effects nor show vasculogenic effects without Matrigel $^{\mathrm{TM}}$ plug assay $[84,85]$. ECFCs' capability to differentiate into ECs and their regenerative and therapeutic effects on vasculature in ischemia need to be troubleshot. Furthermore, because there is no defined line between ECFCs and ECs, the possibilities that these cells are primitive circulating ECs or are ECs sloughed off from vessels still remain to be established.

\section{HEMATOPOIETIC STEM CELLS (HSCs)}

HSCs are multipotent stem cells that have the capacity to give rise to all blood cell types, to commit to lymphoid lineages, and to self-renew [86]. In adult vertebrates, HSCs occupy $<1 \%$ of the total BM cells and constitute 1:10,000 cells in the myeloid tissue. Hematopoietic tissues contain cells in the long- and short-term regenerative capacities and committed multipotent, oligopotent, and unipotent progenitors. Currently, HSCs are one of the best characterized stem cells, due to their lack of markers indicating lineage commitment (lin-) and to the presence of combination of indicating markers, such as CD133, CD34, CD38, CD90 (Thy1), CD105, and CD117 (c-kit) [87-89].

HSCs have been applied for the treatment of hematologic diseases for over three decades. Furthermore, due to their multipotency, HSCs were applied for the regeneration of damaged myocardium $[45,46]$. In these studies, HSCs were shown to be able to transdifferentiate into nonhematopoietic cells, such as cardiomyocytes, ECs, and vascular smooth muscle cells in infarcted heart $[45,46]$. However, some studies have refuted that HSCs, represented by lin-negative, sca1-positive, and c-kit-positive, do not transdifferentiate into any cardiomyocytes, after transplantation, in a mouse MI model [48, 49]. While no other specific human HSCs have been used, human $\mathrm{CD}^{+} 4^{+}[17,27,47,90]$ and $\mathrm{CD}_{133^{+}}$cells [91-93] were used in experiments reporting that post-MI cardiac function has been improved, conversely, through non-cardiomyogenic effects. The need for the use of mobilizing cytokines, such as G-CSF, to collect sufficient amount of CD34+ or CD133+ cells expenses high cost for clinical application and may result in a risk to patients.

\section{BM MONONUCLEAR CELLS (BM-MNCs)}

BM-MNCs are composed of a number of different types of cells, such as hematopoietic cells, fibroblasts, osteoblasts, myogenic cells, and endothelial-lineage cells [94]. BM-MNC transplantation facilitated neovascularization in animal models of acute myocardial ischemia [94, 95] and similar results in humans [96-99]. Because the monocyte/macrophage proportion of BM-MNCs expresses key angiogenic growth factors and cytokines (e.g., VEGF, basic fibroblast growth factor [FGF2], angiopoietin-1 [Ang-1], interleukin [IL]-1 $\beta$, tumor necrosis factor- $\alpha[\mathrm{TNF}-\alpha])$ and stimulates angiogenesis [94, $100,101]$, this cocktail of angiogenic factors mixed in the population may cause paracrine effects that stimulate proliferation, homing, and differentiation of preexisting stem 
cells [102].

On the contrary to some of the beneficial effects exerted by BM-MNCs, lymphocytes and monocytes/macrophages express pro-inflammatory cytokines, such as IL-1, IL-2, IL-6, IL-12, interferon- $\gamma$ (IFN- $\gamma$ ), lymphotoxin, and tumor necrosis factors (TNFs) [103-105], and may cause negative inotropic effect on myocardium. Also, because lymphocytes and monocytes/macrophages, which are inflammatory cells, are a large portion of the MNC population, myocardial damage after MI may be accelerated by these cells as well as severe hemorrhage or inflammation, instigated by the transplanted MNCs, could jeopardize the survival and transdifferentiation of transplanted MNCs [17].

\section{NON-TRANSDIFFERENTIATION THERAPEUTIC EFFECTS OF BM-DERIVED CELLS}

The plasticity, true tissue generation, or transdifferentiation capacity of BM-derived cells has been widely debated, despite promising therapeutic potential [48-50]. Many recent studies suggest that the paracrine mechanism is the primary mechanism that accounts for therapeutic effects in cardiovascular diseases, not vasculogenesis or exogenous myogenesis because vasculogenesis and exogenous myogenesis rarely occur. BM cells release angiogenic factors VEGF, Chemokine (C-C motif) ligand 2, (CCL2, also known as MCP-1), FGF2, Angpt1, and Wnt [94, 106, 107]. It was reported that Wnt signaling mediate angiogenic effects of human fetal $\mathrm{CD}_{133^{+}}$cells on ischemic wounds [107] and that these growth factors stimulate angiogenesis, prevent tissue apoptosis or necrosis, and induce endogenous resident stem cell migration and proliferation via paracrine response $[51,55,57,58,107,108]$. Recent studies reported that humoral effects can be attributed to both implanted cells and the target host tissues receiving the cell therapy [52, 108, 109]. Although fusion as a mechanism for transdifferentiation is well known [110, 111], unlike earlier studies [112, 113], recent studies have discovered that fusion is minimally involved in phenotypic changes of stem cells [58].

\section{HEMATOPOIETIC CD $3 I^{+}$CELLS}

\section{Role of CD3 I in vascular biology}

CD31, also known as platelet endothelial cell adhesion molecule (PECAM)-1, is a $130-\mathrm{kDa}$ transmembrane protein consisting of six extracellular immunoglobulin folds. In its cytoplasmic domain, there are two immunoreceptor tyrosine-based inhibitory motifs (ITIM) for interactions with signaling molecules. CD31 is expressed on the cell surface of ECs and hematopoietic cells, such as monocytes, platelets, neutrophils, natural killer cells, megakaryocytes, and some T cells. CD31 mediates homotypic adhesion between adjacent ECs as well as between ECs and leukocytes [114, 115]. A role of CD31 in migration through ECs has also been reported for neutrophils and monocytes [116], and subsequently for numerous other cell types, including natural killer cells [117], hematopoietic progenitor cells (HPCs) [118] and certain subsets of lymphocytes [119, 120].

Cell-cell and cell-extracellular matrix interactions are two of the essential roles during blood vessel formation and regression. CD31 has been gaining attention as it is being recognized to suppress cell death through interactions, such as homophilic interactions of CD31 that are in between ECs and monocytes [121]. The interaction of CD31 in suppressing apoptosis suggests that CD31 releases pro-survival signals, and the interaction also has been reported to induce Akt, a serine/threonine protein kinase, phosphorylation. On the contrary to apoptosis suppression characteristics, CD31 also assist ECs in apoptosis through metalloproteinase- dependent cleavage and caspase-mediated cleavage of the cytoplasmic tail [122].

Additionally, given that it is expressed abundantly in ECs, CD31 has been shown to be involved in the initial stabilization and formation of cell-cell contacts at lateral junctions of ECs, the maintenance of a vascular permeability barrier, modulation of cell migration, transendothelial migration of monocytes and neutrophils, and formation of blood vessels in angiogenesis $[114,116,123,124]$. Moreover, earlier studies have shown that CD31 formed a functional complex with cadherin 5, $\beta$-catenin, and F-actin to control EC tube formation [125]. However, a later study showed that CD31 was involved in the adhesion/signaling events necessary for the migration of ECs and subsequent tube formation during angiogenesis, independent of VE-cadherin [126].

\section{Identification of specialized multimodal angio-vasculogenic cells}

To advance cell therapy, it seems very crucial to target and identify cells that are specialized for humoral effects, since recent studies almost universally reported that the major therapeutic mechanism of BM-derived stem or progenitor cells is humoral or paracrine effect [52, 55-57]. Therefore, recent studies have used specific surface markers to isolate cells enriched in humoral activities from BM and/or PB $[61,62]$. Using surface makers allows the cells to be isolated without cell culture, which saves costs, and safely evading any harmful effects that may come with using animal serum. In a series of studies, CD31 was used as a marker to find BM-derived cells that have multimodal effects, such as angiogenic, vasculogenic, higher adhesion, and almost exclusive hematopoietic stem/progenitor cell activities (Fig. 1).

\section{Angiogenic activities}

Based on genome-wide gene expression analyses of mouse $\mathrm{BM}$ (mBM), human BM ( $\mathrm{hBM}$ ), and $\mathrm{hPB}$, angiogenic genes were enriched in $\mathrm{CD}^{+} 1^{+}$cells when compared with CD31 cells $[61,62]$. Compared to their negative counterparts, $\mathrm{hBM}-\mathrm{CD} 31^{+}$cells expressed higher levels of heparin-binding EGF-like growth factor (HBEGF), which is active in vascular smooth muscle cell recruitment [127] and IL-8, a macrophage-derived mediator of angiogenesis [128]; mBM-CD31 ${ }^{+}$ cells expressed high levels of Angpt-1, an eminent angiogenic 


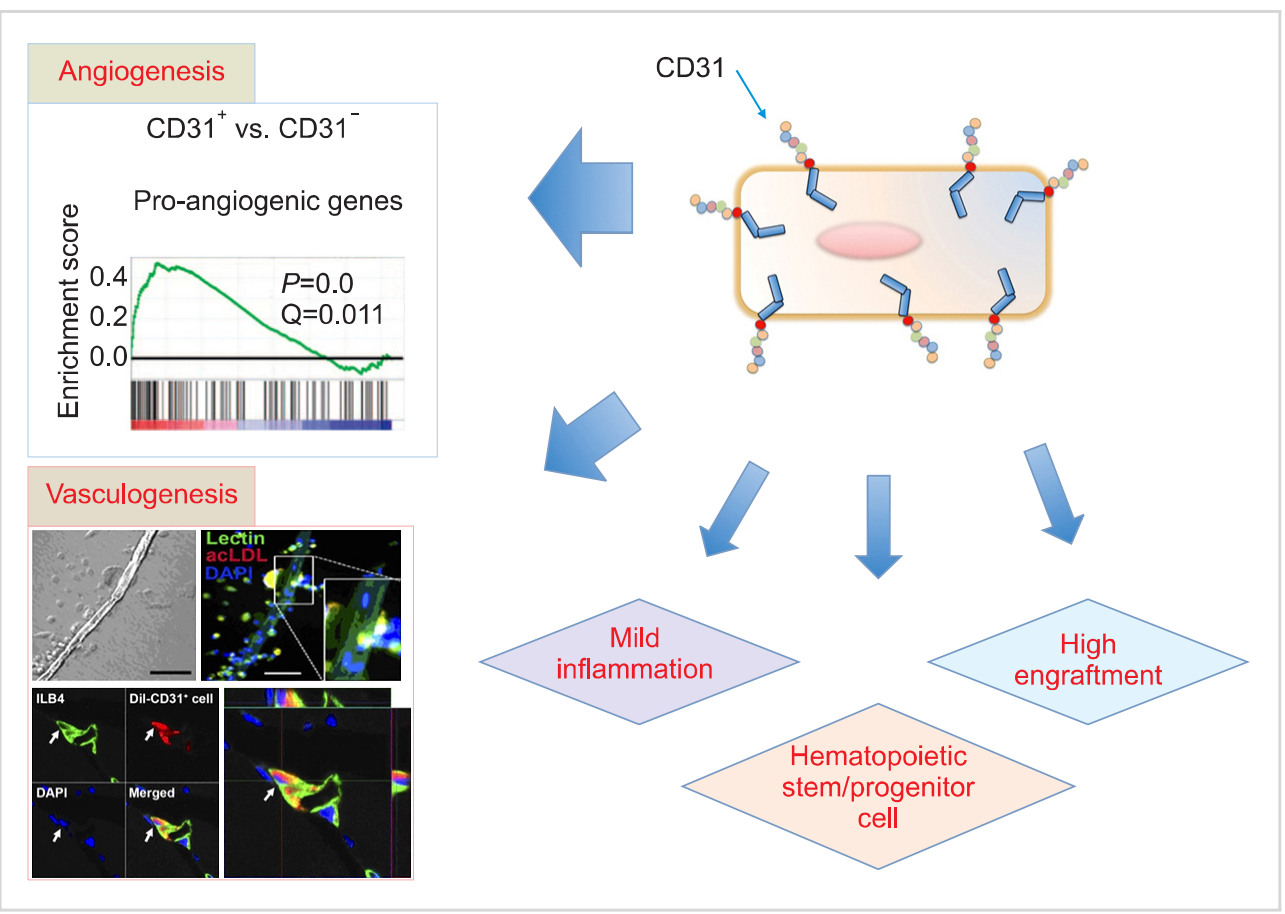

Fig. 1. The multimodal effects of BM-derived hematopoietic CD $31^{+}$ cells. BM-derived $\mathrm{CD} 31^{+}$cells highly expressed pro-angiogenic genes (angiogenicity). BM-derived $\mathrm{CD} 1^{+}$cells showed a high number of EPCs and formed a tubular structure (vasculogenicity). The high adhesion capacity and low inflammatory activity of the cells allowed high engraftment and mild inflammation, respectively. The hematopoietic stem and progenitor cells were enriched in CD $31^{+}$cells (HSC and HPC activity) $[61,62]$. growth factor [129, 130], and GATA2, a transcription factor that proliferates angiogenesis when activated [131]. Similarly, hPB-CD31 ${ }^{+}$expresses extremely high levels of neuropilin-1 (NRP1), which is a necessity in vascular development and a mediator in VEGF-dependent angiogenesis [132], compared with the negative cells.

\section{Vasculogenic properties}

The recurring questions that need to be addressed are whether hematopoietic cells can give rise to ECs [46, 133, 134] and what is the true identity of those cells. A majority of studies, including ours, have demonstrated that BM-derived cells can generate ECs. On the other hand, several studies have refuted such notion $[48,50,135]$ by using MI models to prove vasculogenic effects [48, 49]. However, those refutations are inappropriate since a $\mathrm{MI}$ model accepts minimal amount of engraftment from any cell, including BM-derived cells. Other studies supported our notion that the retention of ESC-derived cardiomyocytes or cardiac stem or progenitor cells was minimal in a MI model as well [136-138]. MI hinders engraftment and survival of any implanted cells, such as constant motion of the heart, inflammation in acute stages of infarction, insufficient oxygen and nutrients, and tight junctions between cardiomyocytes. One study reported that it is common for EC transdifferentiation to occur in transplanted heart samples [139]. In other independent studies, with the correct conditions, such as suitable BM-derived cells with permissive models, BM-derived cells can give rise to ECs $[140,141]$. Based on the results of these studies, cell types and/or environment is very crucial to generating ECs from BM or PB cells.

In recent studies on the vasculogenic effects of $\mathrm{CD} 31^{+}$ cells $[61,62]$, compared with CD31 ${ }^{-}$cells, mBM-, hBM-, and $\mathrm{hPB}-\mathrm{CD} 31^{+}$cells gave rise to a large number of EPCs in culture and expressed EC-specific markers, such as von Willebrand factor, VEGFR-2, VE-cadherin, and CD31. In addition, hPB-CD31 ${ }^{+}$cells formed aggregates and, subsequently, underwent tubular structural changes within the round cell cluster by day 10 followed by the formation of complete linear tubular structure that mimicked in vivo vasculogenesis. This linear tubular structure had stained positive for lectin and took up acetylated human low-density lipoprotein, indicating EC characteristics. In vivo vasculogenesis studies had also been investigated. By using a mouse model of hindlimb ischemia, vasculogenic activities of CD31 ${ }^{+}$ cells had been tested $[61,62]$. However, due to the divisive notion of transdifferentiation potential of BM cells [48, 50, $54,134,140,141]$, the confirmation methods used were rigorous and definitive: confocal microscopy with 3D reconstruction of multiple images were used to clearly demonstrate that a fraction of $\mathrm{CD} 31^{+}$cells were colocalized with the ECs within the vascular structure even up to 8 weeks after; flow cytometric analysis of enzymatically digested hindlimb tissues showed that up to $4 \%$ of the ECs in the ischemic tissues were derived from transplanted $\mathrm{mBM}$ - or $\mathrm{hPB}-\mathrm{CD} 31^{+}$ cells; fluorescent in situ hybridization of the digested tissues further confirmed the contribution of $\mathrm{hPB}-\mathrm{CD} 31^{+}$cells into ECs [62]. This clear adaptation of definitive methods were the first to prove transdifferentiation of hematopoietic cells. Clearly, this experiment had proved that directly injected $\mathrm{CD} 1^{+}$cells give rise to functional ECs in ischemic tissues.

\section{Higher adhesion and engraftment potential}

Low retention of injected cells is one of the major problems that hinder the therapeutic effects of cell therapy because a stable engraftment and a steady survival are needed for 
optimal cell therapy. Studies reported that less than 25\% of engraftment of transplanted neonatal cardiomyocytes were present within 24 hrs of MI in animal models [142] and, similarly, only $5 \%$ of $\mathrm{CD}^{+} 4^{+}$injected cells remained after $1 \mathrm{hr}$ in human patients with MI [143]. Additionally, a majority of the directly injected, cultured early EPCs in myocardium post-MI had disappeared within a week [52]. Cell adhesion is also another crucial factor that can increase survival. Cells that adhere to extracellular matrix have higher chance of survival since they are able to avoid anoikis, an apoptosis caused by the lack of adhesion to extracellular matrix. CD31 was first found as an adhesion molecule [115, 144] and had been shown to mediate cell-cell interaction via hemophilic interactions between CD31-expressing cells [145]. Genome-wide gene expression data showed high levels of genes relevant to adhesion, chemokine production and reception, and extracellular matrix in $\mathrm{CD}^{+} 1^{+}$cells [62]. Furthermore, cell adhesion assay showed that $\mathrm{CD} 31^{+}$cells have the capacity to adhere to more matrix proteins, such as fibronectin, collagen, laminin, and vitronectin [61, 62], than $\mathrm{CD}^{-} 1^{-}$cells can. In vivo samples analyzed by the confocal microscopy and FACS analysis confirmed higher engraftment and survival of injected $\mathrm{CD}^{+} 1^{+}$cells compared to the $\mathrm{CD}^{-} 1^{-}$cells or MNCs.

Although CXCR4/SDF-1 is a recognized signaling axis to mediate cell engraftment and migration, the engraftment of $\mathrm{CD}^{+} 1^{+}$cells do not depend on this axis because, when the levels of CXCR4 were measured, there was no difference in the expression between $\mathrm{CD} 31^{+}$and $\mathrm{CD}^{-} 1^{-}$cells. On the other hand, CD31 molecules and other adhesion molecules, ICAM4 4 and integrin $\alpha$, which were expressed more in $\mathrm{CD} 31^{+}$ cells than CD31 ${ }^{-}$cells, could have been involved in the higher engraftment of $\mathrm{CD} 31^{+}$cells. The higher engraftment of $\mathrm{CD} 31^{+}$cells would allow mBM- and hPB-CD31 ${ }^{+}$cells to increase angiogenic and vasculogenic capabilities.

\section{Enriched HSCs \& hematopoietic progenitor cells (HPCs)}

According to the gene expression studies, hematopoietic stem and progenitor cell gene levels were reported to be higher in $\mathrm{mBM}-\mathrm{CD} 31^{+}$cells and in $\mathrm{hBM}-\mathrm{CD} 31^{+}$cells than in their corresponding negative cells, suggesting that more hematopoietic stem and progenitor cells are expected to be found in $\mathrm{CD} 1^{+}$cell population. Concurrent with this hypothesis, according to in vitro colony-forming assay and in vivo $\mathrm{BM}$ cell transplantation, hematopoietic stem and progenitor cells are almost exclusively found in mBM-CD31 ${ }^{+}$ cells; also, more than $90 \%$ of HSCs, multipotent progenitor cells, common lymphoid progenitor cells, and common myeloid progenitor cells in mBM express CD31 [61]. Similarly, in humans, CD31 was expressed in $99.8 \%$ of $\mathrm{CD}^{+} 4^{+} \mathrm{CD} 133^{+}$ and $89 \%$ of $\mathrm{CD} 34^{+} \mathrm{CD} 133^{-} \mathrm{hBM}$ cells, and clonogenic HPCs are found in $\mathrm{hPB}-\mathrm{CD} 31^{+}$cells [62]. These findings suggest that HSCs and HPCs are heavily enriched in the CD31 ${ }^{+}$ cell population.

There is some possibility that HSCs or HPCs included in the $\mathrm{CD}_{3} 1^{+}$population could have played a role in ischemic tissue repair because $\mathrm{CD} 34^{+}$cells, which include most HSC and EPCs, were known to be effective for treating ischemic cardiovascular diseases in animal models and human patients. Since the therapeutic effects of hBM-CD $34^{-} \mathrm{CD} 31^{+}$cells and $\mathrm{hBM}-\mathrm{CD} 34^{+}$cells were reported to be similar in improving mouse limb ischemia, it is more likely that non-HSCs could play a significant role in improving limb ischemia and/or therapeutic neovascularization.

\section{CLINICAL APPLICATION}

CD31 is the first marker that was used to isolate BM or $\mathrm{PB}$ cell subpopulation based on recent discovery on the mechanisms. With such isolation methods, cell mobilization can be avoided, and more effective, safe, and promising cell therapy can be developed to treat patients with advanced ischemic cardiovascular diseases. Approximately 30-35\% of the total MNCs from $\mathrm{hPB}$ are $\mathrm{CD} 31^{+}$cells, which make them a better selection over either $\mathrm{CD} 34^{+}$or $\mathrm{CD} 133^{+}$cells [146, 147]. Due to such characteristics, the use of mobilizing agents, such as G-CSF, is not required for $\mathrm{CD}^{+} 1^{+}$cell collection [26, 146]. Moreover, unlike cultured EPCs or MSCs, $\mathrm{CD} 1^{+}$cells do not need cell culture, which can develop harmful side effects. The current cell culture condition of EPCs and MSCs use fetal bovine serum that may develop the risk of disease transmission through viral, prion, and zoonose contamination or immunological effects [148]. Similarly, the uncultured BM-derived MNCs or unfractionated cells are deemed inferior to $\mathrm{CD}^{+} 1^{+}$cells, because BM-derived MNCs include unnecessary cells that have potential risks, such as calcification [149] and aggravation of ischemia [150], while no such adverse effects have been reported in $\mathrm{CD}^{+} 1^{+}$cells $[61,62]$. Therefore, after having isolated $\mathrm{CD}^{+} 1^{+}$cells from nonangiogenic and highly inflammatory $\mathrm{CD} 31^{-}$cells, $\mathrm{CD} 31^{+}$population can be utilized for higher therapeutic uses with smaller risks.

\section{CONCLUSION}

More investigation is needed to identify more angiogenic and/or vasculogenic cells for better efficiency and potency, since $\mathrm{CD}^{+} 1^{+}$cell population is heterogeneous, including $\mathrm{T}$ and B lymphocytes and myelomonocytic cells. Since CD31 ${ }^{+}$ cells have been proven experimentally, the following studies should be clinical trials, starting with patients with critical limb ischemia or non-healing wounds. Also, since peripheral tissues provide more room for engraftment and less hostile environment for survival, critical limb ischemia should be an optimal introductory target to treat with $\mathrm{CD}^{+} 1^{+}$cells. Furthermore, with success, cell therapy with $\mathrm{CD} 31^{+}$cells could be expanded to treating other ischemic cardiovascular diseases, such as MI and stroke.

After a decade of investigating and experimenting different perspectives of cell therapy, the importance of humoral and paracrine mechanism, host environment in cell engraftment and therapeutic effects, and selected cells has been discovered 
and such knowledge has caused us to rethink and revamp our approach to cell therapy. If tissue generation from transplanted cells is not needed, instead of using stem or progenitor cells that are few and require much handling, using specialized angiogenic and/or vasculogenic effector cells and tailored treatment based on specific diseases should be the next aim in therapeutic effects.

\section{Authors' Disclosures of Potential Conflicts of Interest}

No potential conflicts of interest relevant to this article were reported.

\section{REFERENCES}

1. Roger VL, Go AS, Lloyd-Jones DM, et al. Heart disease and stroke statistics-2011 update: a report from the American Heart Association. Circulation 2011;123:e18-e209.

2. Feinglass J, Sohn MW, Rodriguez H, Martin GJ, Pearce WH. Perioperative outcomes and amputation-free survival after lower extremity bypass surgery in California hospitals, 19961999, with follow-up through 2004. J Vasc Surg 2009;50:776-83. e1.

3. Taylor SM, Kalbaugh CA, Blackhurst DW, Kellicut DC, Langan EM 3rd, Youkey JR. A comparison of percutaneous transluminal angioplasty versus amputation for critical limb ischemia in patients unsuitable for open surgery. J Vasc Surg 2007;45:304-10.

4. Fang J, Mensah GA, Croft JB, Keenan NL. Heart failure-related hospitalization in the U.S., 1979 to 2004. J Am Coll Cardiol 2008;52:428-34.

5. Bifari F, Pacelli L, Krampera M. Immunological properties of embryonic and adult stem cells. World J Stem Cells 2010;2:50-60.

6. Cao F, Lin S, Xie X, et al. In vivo visualization of embryonic stem cell survival, proliferation, and migration after cardiac delivery. Circulation 2006;113:1005-14.

7. Takahashi K, Tanabe K, Ohnuki M, et al. Induction of pluripotent stem cells from adult human fibroblasts by defined factors. Cell 2007;131:861-72.

8. Takahashi K, Yamanaka S. Induction of pluripotent stem cells from mouse embryonic and adult fibroblast cultures by defined factors. Cell 2006;126:663-76.

9. Hacein-Bey-Abina S, Von Kalle C, Schmidt M, et al. LMO2associated clonal $\mathrm{T}$ cell proliferation in two patients after gene therapy for SCID-X1. Science 2003;302:415-9.

10. Kim K, Doi A, Wen B, et al. Epigenetic memory in induced pluripotent stem cells. Nature 2010;467:285-90.

11. Polo JM, Liu S, Figueroa ME, et al. Cell type of origin influences the molecular and functional properties of mouse induced pluripotent stem cells. Nat Biotechnol 2010;28:848-55.

12. Dhodapkar KM, Feldman D, Matthews $P$, et al. Natural immunity to pluripotency antigen OCT4 in humans. Proc Natl Acad Sci U S A 2010;107:8718-23.

13. Zhao T, Zhang ZN, Rong Z, Xu Y. Immunogenicity of induced pluripotent stem cells. Nature 2011;474:212-5.

14. Kalka C, Masuda $H$, Takahashi $T$, et al. Transplantation of ex vivo expanded endothelial progenitor cells for therapeutic neovascularization. Proc Natl Acad Sci U S A 2000;97:3422-7.

15. Murohara T, Ikeda H, Duan J, et al. Transplanted cord bloodderived endothelial precursor cells augment postnatal neovascularization. J Clin Invest 2000;105:1527-36.

16. Kawamoto A, Gwon HC, Iwaguro H, et al. Therapeutic potential of ex vivo expanded endothelial progenitor cells for myocardial ischemia. Circulation 2001;103:634-7.

17. Kawamoto A, Iwasaki H, Kusano K, et al. CD34-positive cells exhibit increased potency and safety for therapeutic neovascularization after myocardial infarction compared with total mononuclear cells. Circulation 2006;114:2163-9.

18. Jeong JO, Kim MO, Kim H, et al. Dual angiogenic and neurotrophic effects of bone marrow-derived endothelial progenitor cells on diabetic neuropathy. Circulation 2009;119: 699-708.

19. Schatteman GC, Hanlon HD, Jiao C, Dodds SG, Christy BA. Blood-derived angioblasts accelerate blood-flow restoration in diabetic mice. J Clin Invest 2000;106:571-8.

20. Kocher AA, Schuster MD, Szabolcs MJ, et al. Neovascularization of ischemic myocardium by human bone-marrow-derived angioblasts prevents cardiomyocyte apoptosis, reduces remodeling and improves cardiac function. Nat Med 2001;7:430-6.

21. Iwasaki H, Kawamoto A, Ishikawa M, et al. Dose-dependent contribution of CD34-positive cell transplantation to concurrent vasculogenesis and cardiomyogenesis for functional regenerative recovery after myocardial infarction. Circulation 2006;113:1311-25.

22. Bartunek J, Vanderheyden M, Vandekerckhove B, et al. Intracoronary injection of CD133-positive enriched bone marrow progenitor cells promotes cardiac recovery after recent myocardial infarction: feasibility and safety. Circulation 2005;112(9 Suppl):I178-83.

23. Li ZQ, Zhang M, Jing YZ, et al. The clinical study of autologous peripheral blood stem cell transplantation by intracoronary infusion in patients with acute myocardial infarction (AMI). Int J Cardiol 2007;115:52-6.

24. Boyle AJ, Whitbourn R, Schlicht S, et al. Intra-coronary high-dose CD34+ stem cells in patients with chronic ischemic heart disease: a 12-month follow-up. Int J Cardiol 2006;109:21-7.

25. Stamm C, Kleine HD, Choi YH, et al. Intramyocardial delivery of CD133+ bone marrow cells and coronary artery bypass grafting for chronic ischemic heart disease: safety and efficacy studies. J Thorac Cardiovasc Surg 2007;133:717-25.

26. Losordo DW, Henry TD, Davidson C, et al. Intramyocardial, autologous CD34+ cell therapy for refractory angina. Circ Res 2011;109:428-36.

27. Losordo DW, Schatz RA, White CJ, et al. Intramyocardial transplantation of autologous CD34+ stem cells for intractable angina: a phase I/IIa double-blind, randomized controlled trial. Circulation 2007;115:3165-72.

28. Burt RK, Testori A, Oyama Y, et al. Autologous peripheral blood CD133+ cell implantation for limb salvage in patients with critical limb ischemia. Bone Marrow Transplant 2010;45:111-6.

29. Kuroda R, Matsumoto T, Miwa M, et al. Local transplantation of G-CSF-mobilized CD34(+) cells in a patient with tibial nonunion: a case report. Cell Transplant 2011;20:1491-6. 
30. Assmus B, Schachinger V, Teupe C, et al. Transplantation of Progenitor Cells and Regeneration Enhancement in Acute Myocardial Infarction (TOPCARE-AMI). Circulation 2002;106: 3009-17.

31. Hare JM, Traverse JH, Henry TD, et al. A randomized, doubleblind, placebo-controlled, dose-escalation study of intravenous adult human mesenchymal stem cells (prochymal) after acute myocardial infarction. J Am Coll Cardiol 2009;54:2277-86.

32. Assmus B, Honold J, Schächinger V, et al. Transcoronary transplantation of progenitor cells after myocardial infarction. N Engl J Med 2006;355:1222-32.

33. Tatsumi T, Ashihara E, Yasui T, et al. Intracoronary transplantation of non-expanded peripheral blood-derived mononuclear cells promotes improvement of cardiac function in patients with acute myocardial infarction. Circ J 2007;71: 1199-207.

34. Schaefer A, Meyer GP, Fuchs M, et al. Impact of intracoronary bone marrow cell transfer on diastolic function in patients after acute myocardial infarction: results from the BOOST trial. Eur Heart J 2006;27:929-35.

35. Janssens S, Dubois C, Bogaert J, et al. Autologous bone marrowderived stem-cell transfer in patients with ST-segment elevation myocardial infarction: double-blind, randomised controlled trial. Lancet 2006;367:113-21.

36. Lunde K, Solheim S, Aakhus S, et al. Intracoronary injection of mononuclear bone marrow cells in acute myocardial infarction. N Engl J Med 2006;355:1199-209.

37. Meyer GP, Wollert KC, Lotz J, et al. Intracoronary bone marrow cell transfer after myocardial infarction: eighteen months' follow-up data from the randomized, controlled BOOST (BOne marrOw transfer to enhance ST-elevation infarct regeneration) trial. Circulation 2006;113:1287-94.

38. Penicka M, Horak J, Kobylka P, et al. Intracoronary injection of autologous bone marrow-derived mononuclear cells in patients with large anterior acute myocardial infarction: a prematurely terminated randomized study. J Am Coll Cardiol 2007;49: 2373-4.

39. Asahara T, Masuda H, Takahashi T, et al. Bone marrow origin of endothelial progenitor cells responsible for postnatal vasculogenesis in physiological and pathological neovascularization. Circ Res 1999;85:221-8.

40. Masuda H, Kalka C, Takahashi T, et al. Estrogen-mediated endothelial progenitor cell biology and kinetics for physiological postnatal vasculogenesis. Circ Res 2007;101:598-606.

41. Bauer SM, Goldstein LJ, Bauer RJ, Chen H, Putt M, Velazquez OC. The bone marrow-derived endothelial progenitor cell response is impaired in delayed wound healing from ischemia. J Vasc Surg 2006;43:134-41.

42. Ii M, Nishimura H, Iwakura A, et al. Endothelial progenitor cells are rapidly recruited to myocardium and mediate protective effect of ischemic preconditioning via "imported" nitric oxide synthase activity. Circulation 2005;111:1114-20.

43. Iwakura A, Shastry S, Luedemann C, et al. Estradiol enhances recovery after myocardial infarction by augmenting incorporation of bone marrow-derived endothelial progenitor cells into sites of ischemia-induced neovascularization via endothelial nitric oxide synthase-mediated activation of matrix metalloproteinase-9. Circulation 2006;113:1605-14.

44. Murayama T, Tepper OM, Silver M, et al. Determination of bone marrow-derived endothelial progenitor cell significance in angiogenic growth factor-induced neovascularization in vivo. Exp Hematol 2002;30:967-72.

45. Jackson KA, Majka SM, Wang H, et al. Regeneration of ischemic cardiac muscle and vascular endothelium by adult stem cells. J Clin Invest 2001;107:1395-402.

46. Orlic D, Kajstura J, Chimenti S, et al. Bone marrow cells regenerate infarcted myocardium. Nature 2001;410:701-5.

47. Yeh ET, Zhang S, Wu HD, Körbling M, Willerson JT, Estrov Z. Transdifferentiation of human peripheral blood CD34+-enriched cell population into cardiomyocytes, endothelial cells, and smooth muscle cells in vivo. Circulation 2003;108:2070-3.

48. Balsam LB, Wagers AJ, Christensen JL, Kofidis T, Weissman IL, Robbins RC. Haematopoietic stem cells adopt mature haematopoietic fates in ischaemic myocardium. Nature 2004;428: 668-73.

49. Murry CE, Soonpaa MH, Reinecke H, et al. Haematopoietic stem cells do not transdifferentiate into cardiac myocytes in myocardial infarcts. Nature 2004;428:664-8.

50. Ziegelhoeffer T, Fernandez B, Kostin S, et al. Bone marrowderived cells do not incorporate into the adult growing vasculature. Circ Res 2004;94:230-8.

51. Urbich C, Aicher A, Heeschen C, et al. Soluble factors released by endothelial progenitor cells promote migration of endothelial cells and cardiac resident progenitor cells. J Mol Cell Cardiol 2005;39:733-42.

52. Cho HJ, Lee N, Lee JY, et al. Role of host tissues for sustained humoral effects after endothelial progenitor cell transplantation into the ischemic heart. J Exp Med 2007;204:3257-69.

53. Miyamoto Y, Suyama T, Yashita T, Akimaru H, Kurata H. Bone marrow subpopulations contain distinct types of endothelial progenitor cells and angiogenic cytokine-producing cells. J Mol Cell Cardiol 2007;43:627-35.

54. Rehman J, Li J, Orschell CM, March KL. Peripheral blood "endothelial progenitor cells" are derived from monocyte/ macrophages and secrete angiogenic growth factors. Circulation 2003;107:1164-9.

55. Gnecchi M, He H, Liang OD, et al. Paracrine action accounts for marked protection of ischemic heart by Akt-modified mesenchymal stem cells. Nat Med 2005;11:367-8.

56. Uemura R, Xu M, Ahmad N, Ashraf M. Bone marrow stem cells prevent left ventricular remodeling of ischemic heart through paracrine signaling. Circ Res 2006;98:1414-21.

57. Kinnaird T, Stabile E, Burnett MS, et al. Local delivery of marrow-derived stromal cells augments collateral perfusion through paracrine mechanisms. Circulation 2004;109:1543-9.

58. Yoon YS, Wecker A, Heyd L, et al. Clonally expanded novel multipotent stem cells from human bone marrow regenerate myocardium after myocardial infarction. J Clin Invest 2005;115: 326-38.

59. Mirotsou M, Zhang Z, Deb A, et al. Secreted frizzled related protein 2 (Sfrp2) is the key Akt-mesenchymal stem cell-released paracrine factor mediating myocardial survival and repair. Proc Natl Acad Sci U S A 2007;104:1643-8.

60. He W, Zhang L, Ni A, et al. Exogenously administered secreted 
frizzled related protein 2 (Sfrp2) reduces fibrosis and improves cardiac function in a rat model of myocardial infarction. Proc Natl Acad Sci U S A 2010;107:21110-5.

61. Kim H, Cho HJ, Kim SW, et al. CD31+ cells represent highly angiogenic and vasculogenic cells in bone marrow: novel role of nonendothelial CD31+ cells in neovascularization and their therapeutic effects on ischemic vascular disease. Circ Res 2010; 107:602-14.

62. Kim SW, Kim H, Cho HJ, Lee JU, Levit R, Yoon YS. Human peripheral blood-derived CD31+ cells have robust angiogenic and vasculogenic properties and are effective for treating ischemic vascular disease. J Am Coll Cardiol 2010;56:593-607.

63. Asahara T, Murohara T, Sullivan A, et al. Isolation of putative progenitor endothelial cells for angiogenesis. Science 1997;275: 964-7.

64. Dimmeler S, Burchfield J, Zeiher AM. Cell-based therapy of myocardial infarction. Arterioscler Thromb Vasc Biol 2008;28: 208-16.

65. Kawamoto A, Losordo DW. Endothelial progenitor cells for cardiovascular regeneration. Trends Cardiovasc Med 2008;18: 33-7.

66. Bertolini F, Mancuso P, Shaked Y, Kerbel RS. Molecular and cellular biomarkers for angiogenesis in clinical oncology. Drug Discov Today 2007;12:806-12.

67. Bertolini F, Shaked Y, Mancuso P, Kerbel RS. The multifaceted circulating endothelial cell in cancer: towards marker and target identification. Nat Rev Cancer 2006;6:835-45.

68. Schatteman GC, Dunnwald M, Jiao C. Biology of bone marrowderived endothelial cell precursors. Am J Physiol Heart Circ Physiol 2007;292:H1-18.

69. Fernandez Pujol B, Lucibello FC, Gehling UM, et al. Endothelial-like cells derived from human CD14 positive monocytes. Differentiation 2000;65:287-300.

70. Dimmeler S, Zeiher AM. Endothelial cell apoptosis in angiogenesis and vessel regression. Circ Res 2000;87:434-9.

71. Dimmeler S, Aicher A, Vasa M, et al. HMG-CoA reductase inhibitors (statins) increase endothelial progenitor cells via the PI 3-kinase/Akt pathway. J Clin Invest 2001;108:391-7.

72. Schmeisser A, Garlichs CD, Zhang H, et al. Monocytes coexpress endothelial and macrophagocytic lineage markers and form cord-like structures in Matrigel under angiogenic conditions. Cardiovasc Res 2001;49:671-80.

73. Ingram DA, Caplice NM, Yoder MC. Unresolved questions, changing definitions, and novel paradigms for defining endothelial progenitor cells. Blood 2005;106:1525-31.

74. Gulati R, Jevremovic D, Peterson TE, et al. Diverse origin and function of cells with endothelial phenotype obtained from adult human blood. Circ Res 2003;93:1023-5.

75. Wang $\mathrm{X}$, Willenbring $\mathrm{H}$, Akkari $\mathrm{Y}$, et al. Cell fusion is the principal source of bone-marrow-derived hepatocytes. Nature 2003;422:897-901.

76. Kucia M, Dawn B, Hunt G, et al. Cells expressing early cardiac markers reside in the bone marrow and are mobilized into the peripheral blood after myocardial infarction. Circ Res 2004;95:1191-9.

77. Ratajczak MZ, Kucia M, Reca R, Majka M, Janowska-Wieczorek A, Ratajczak J. Stem cell plasticity revisited: CXCR4-positive cells expressing mRNA for early muscle, liver and neural cells 'hide out' in the bone marrow. Leukemia 2004;18:29-40.

78. Zhang S, Wang D, Estrov Z, Raj S, Willerson JT, Yeh ET. Both cell fusion and transdifferentiation account for the transformation of human peripheral blood CD34-positive cells into cardiomyocytes in vivo. Circulation 2004;110:3803-7.

79. Folkman J. Angiogenesis in cancer, vascular, rheumatoid and other disease. Nat Med 1995;1:27-31.

80. Kawamoto A, Tkebuchava T, Yamaguchi J, et al. Intramyocardial transplantation of autologous endothelial progenitor cells for therapeutic neovascularization of myocardial ischemia. Circulation 2003;107:461-8.

81. Murohara T. Therapeutic vasculogenesis using human cord blood-derived endothelial progenitors. Trends Cardiovasc Med 2001;11:303-7.

82. Stamm C, Westphal B, Kleine HD, et al. Autologous bonemarrow stem-cell transplantation for myocardial regeneration. Lancet 2003;361:45-6.

83. Döbert N, Britten M, Assmus B, et al. Transplantation of progenitor cells after reperfused acute myocardial infarction: evaluation of perfusion and myocardial viability with FDG-PET and thallium SPECT. Eur J Nucl Med Mol Imaging 2004;31:1146-51.

84. Ingram DA, Mead LE, Tanaka H, et al. Identification of a novel hierarchy of endothelial progenitor cells using human peripheral and umbilical cord blood. Blood 2004;104:2752-60.

85. Yoon CH, Hur J, Park KW, et al. Synergistic neovascularization by mixed transplantation of early endothelial progenitor cells and late outgrowth endothelial cells: the role of angiogenic cytokines and matrix metalloproteinases. Circulation 2005;112: 1618-27.

86. Reya T, Morrison SJ, Clarke MF, Weissman IL. Stem cells, cancer, and cancer stem cells. Nature 2001;414:105-11.

87. Spangrude GJ, Heimfeld S, Weissman IL. Purification and characterization of mouse hematopoietic stem cells. Science 1988;241:58-62.

88. Baum CM, Weissman IL, Tsukamoto AS, Buckle AM, Peault B. Isolation of a candidate human hematopoietic stem-cell population. Proc Natl Acad Sci U S A 1992;89:2804-8.

89. Seita J, Weissman IL. Hematopoietic stem cell: self-renewal versus differentiation. Wiley Interdiscip Rev Syst Biol Med 2010;2:640-53.

90. Wang J, Zhang S, Rabinovich B, et al. Human CD34+ cells in experimental myocardial infarction: long-term survival, sustained functional improvement, and mechanism of action. Circ Res 2010;106:1904-11.

91. Flores-Ramirez R, Uribe-Longoria A, Rangel-Fuentes MM, et al. Intracoronary infusion of CD133+ endothelial progenitor cells improves heart function and quality of life in patients with chronic post-infarct heart insufficiency. Cardiovasc Revasc Med 2010;11:72-8.

92. Schots R, De Keulenaer G, Schoors D, et al. Evidence that intracoronary-injected $\mathrm{CD} 133+$ peripheral blood progenitor cells home to the myocardium in chronic postinfarction heart failure. Exp Hematol 2007;35:1884-90.

93. Leor J, Guetta E, Feinberg MS, et al. Human umbilical cord blood-derived CD133+ cells enhance function and repair of the 
infarcted myocardium. Stem Cells 2006;24:772-80.

94. Kamihata H, Matsubara H, Nishiue T, et al. Implantation of bone marrow mononuclear cells into ischemic myocardium enhances collateral perfusion and regional function via side supply of angioblasts, angiogenic ligands, and cytokines. Circulation 2001;104:1046-52.

95. Fuchs S, Baffour R, Zhou YF, et al. Transendocardial delivery of autologous bone marrow enhances collateral perfusion and regional function in pigs with chronic experimental myocardial ischemia. J Am Coll Cardiol 2001;37:1726-32.

96. Strauer BE, Brehm M, Zeus T, et al. Repair of infarcted myocardium by autologous intracoronary mononuclear bone marrow cell transplantation in humans. Circulation 2002;106: 1913-8.

97. Tateishi-Yuyama E, Matsubara H, Murohara T, et al. Therapeutic angiogenesis for patients with limb ischaemia by autologous transplantation of bone-marrow cells: a pilot study and a randomised controlled trial. Lancet 2002;360:427-35.

98. Perin EC, Dohmann HF, Borojevic R, et al. Transendocardial, autologous bone marrow cell transplantation for severe, chronic ischemic heart failure. Circulation 2003;107:2294-302.

99. Mocini D, Staibano M, Mele L, et al. Autologous bone marrow mononuclear cell transplantation in patients undergoing coronary artery bypass grafting. Am Heart J 2006;151:192-7.

100. Leibovich SJ, Polverini PJ, Shepard HM, Wiseman DM, Shively $\mathrm{V}$, Nuseir N. Macrophage-induced angiogenesis is mediated by tumour necrosis factor-alpha. Nature 1987;329:630-2.

101. Giulian D, Woodward J, Young DG, Krebs JF, Lachman LB. Interleukin-1 injected into mammalian brain stimulates astrogliosis and neovascularization. J Neurosci 1988;8:2485-90.

102. Toda H, Tsuji M, Nakano I, et al. Stem cell-derived neural stem/progenitor cell supporting factor is an autocrine/paracrine survival factor for adult neural stem/progenitor cells. J Biol Chem 2003;278:35491-500.

103. O'Garra A, Murphy K. Role of cytokines in development of Th1 and Th2 cells. Chem Immunol 1996;63:1-13.

104. Mosmann TR. Properties and functions of interleukin-10. Adv Immunol 1994;56:1-26.

105. Chandrasekar B, Mitchell DH, Colston JT, Freeman GL. Regulation of CCAAT/Enhancer binding protein, interleukin-6, interleukin-6 receptor, and gp130 expression during myocardial ischemia/reperfusion. Circulation 1999;99:427-33.

106. Fuchs U, Zittermann A, Suhr O, et al. Heart transplantation in a 68-year-old patient with senile systemic amyloidosis. Am J Transplant 2005;5:1159-62.

107. Barcelos LS, Duplaa C, Krankel N, et al. Human CD133+ progenitor cells promote the healing of diabetic ischemic ulcers by paracrine stimulation of angiogenesis and activation of Wnt signaling. Circ Res 2009;104:1095-102.

108. Tolar J, Nauta AJ, Osborn MJ, et al. Sarcoma derived from cultured mesenchymal stem cells. Stem Cells 2007;25:371-9.

109. Tateno K, Minamino T, Toko H, et al. Critical roles of musclesecreted angiogenic factors in therapeutic neovascularization. Circ Res 2006;98:1194-202.

110. Terada N, Hamazaki T, Oka M, et al. Bone marrow cells adopt the phenotype of other cells by spontaneous cell fusion. Nature 2002;416:542-5.
111. Ying QL, Nichols J, Evans EP, Smith AG. Changing potency by spontaneous fusion. Nature 2002;416:545-8.

112. Nygren JM, Jovinge $S$, Breitbach $M$, et al. Bone marrow-derived hematopoietic cells generate cardiomyocytes at a low frequency through cell fusion, but not transdifferentiation. Nat Med 2004;10:494-501.

113. Alvarez-Dolado M, Pardal R, Garcia-Verdugo JM, et al. Fusion of bone-marrow-derived cells with Purkinje neurons, cardiomyocytes and hepatocytes. Nature 2003;425:968-73.

114. Albelda SM, Muller WA, Buck CA, Newman PJ. Molecular and cellular properties of PECAM-1 (endoCAM/CD31): a novel vascular cell-cell adhesion molecule. J Cell Biol 1991;114: 1059-68.

115. Xie Y, Muller WA. Molecular cloning and adhesive properties of murine platelet/endothelial cell adhesion molecule 1. Proc Natl Acad Sci U S A 1993;90:5569-73.

116. Muller WA, Weigl SA, Deng X, Phillips DM. PECAM-1 is required for transendothelial migration of leukocytes. J Exp Med 1993;178:449-60.

117. Berman ME, Xie Y, Muller WA. Roles of platelet/endothelial cell adhesion molecule-1 (PECAM-1, CD31) in natural killer cell transendothelial migration and beta 2 integrin activation. J Immunol 1996;156:1515-24.

118. Voermans C, Rood PM, Hordijk PL, Gerritsen WR, van der Schoot CE. Adhesion molecules involved in transendothelial migration of human hematopoietic progenitor cells. Stem Cells 2000;18:435-43.

119. Zocchi MR, Ferrero E, Leone BE, et al. CD31/PECAM-1-driven chemokine-independent transmigration of human T lymphocytes. Eur J Immunol 1996;26:759-67.

120. Schenkel AR, Chew TW, Muller WA. Platelet endothelial cell adhesion molecule deficiency or blockade significantly reduces leukocyte emigration in a majority of mouse strains. J Immunol 2004;173:6403-8.

121. Noble KE, Wickremasinghe RG, DeCornet C, Panayiotidis $P$, Yong KL. Monocytes stimulate expression of the Bcl-2 family member, A1, in endothelial cells and confer protection against apoptosis. J Immunol 1999;162:1376-83.

122. Ilan N, Mohsenin A, Cheung L, Madri JA. PECAM-1 shedding during apoptosis generates a membrane-anchored truncated molecule with unique signaling characteristics. FASEB J 2001;15:362-72.

123. Newman PJ, Berndt MC, Gorski J, et al. PECAM-1 (CD31) cloning and relation to adhesion molecules of the immunoglobulin gene superfamily. Science 1990;247:1219-22.

124. DeLisser HM, Christofidou-Solomidou M, Strieter RM, et al. Involvement of endothelial PECAM-1/CD31 in angiogenesis. Am J Pathol 1997;151:671-7.

125. Matsumura T, Wolff K, Petzelbauer P. Endothelial cell tube formation depends on cadherin 5 and CD31 interactions with filamentous actin. J Immunol 1997;158:3408-16.

126. Cao G, O'Brien CD, Zhou Z, et al. Involvement of human PECAM-1 in angiogenesis and in vitro endothelial cell migration. Am J Physiol Cell Physiol 2002;282:C1181-90.

127. Iivanainen E, Nelimarkka L, Elenius V, et al. Angiopoietinregulated recruitment of vascular smooth muscle cells by endothelial-derived heparin binding EGF-like growth factor. 
FASEB J 2003;17:1609-21.

128. Koch AE, Polverini PJ, Kunkel SL, et al. Interleukin-8 as a macrophage-derived mediator of angiogenesis. Science 1992; 258:1798-801.

129. Cho CH, Kammerer RA, Lee HJ, et al. COMP-Ang1: a designed angiopoietin-1 variant with nonleaky angiogenic activity. Proc Natl Acad Sci U S A 2004;101:5547-52.

130. Jones N, Iljin K, Dumont DJ, Alitalo K. Tie receptors: new modulators of angiogenic and lymphangiogenic responses. Nat Rev Mol Cell Biol 2001;2:257-67.

131. Mammoto A, Connor KM, Mammoto T, et al. A mechanosensitive transcriptional mechanism that controls angiogenesis. Nature 2009;457:1103-8.

132. Lee P, Goishi K, Davidson AJ, Mannix R, Zon L, Klagsbrun M. Neuropilin-1 is required for vascular development and is a mediator of VEGF-dependent angiogenesis in zebrafish. Proc Natl Acad Sci U S A 2002;99:10470-5.

133. Shi Q Rafii S, Wu MH, et al. Evidence for circulating bone marrow-derived endothelial cells. Blood 1998;92:362-7.

134. Lyden D, Hattori K, Dias S, et al. Impaired recruitment of bone-marrow-derived endothelial and hematopoietic precursor cells blocks tumor angiogenesis and growth. Nat Med 2001;7: 1194-201.

135. O'Neill TJ 4th, Wamhoff BR, Owens GK, Skalak TC. Mobilization of bone marrow-derived cells enhances the angiogenic response to hypoxia without transdifferentiation into endothelial cells. Circ Res 2005;97:1027-35.

136. Smits AM, van Laake LW, den Ouden K, et al. Human cardiomyocyte progenitor cell transplantation preserves long-term function of the infarcted mouse myocardium. Cardiovasc Res 2009;83:527-35.

137. Tang XL, Rokosh DG, Guo Y, Bolli R. Cardiac progenitor cells and bone marrow-derived very small embryonic-like stem cells for cardiac repair after myocardial infarction. Circ J 2010;74: 390-404

138. Smith RR, Barile L, Cho HC, et al. Regenerative potential of cardiosphere-derived cells expanded from percutaneous endomyocardial biopsy specimens. Circulation 2007;115:896-908.

139. Virag JI, Murry CE. Myofibroblast and endothelial cell proliferation during murine myocardial infarct repair. Am J Pathol 2003;163:2433-40.

140. Gao D, Nolan DJ, Mellick AS, Bambino K, McDonnell K, Mittal
V. Endothelial progenitor cells control the angiogenic switch in mouse lung metastasis. Science 2008;319:195-8.

141. Nolan DJ, Ciarrocchi A, Mellick AS, et al. Bone marrow-derived endothelial progenitor cells are a major determinant of nascent tumor neovascularization. Genes Dev 2007;21:1546-58.

142. Müller-Ehmsen J, Whittaker P, Kloner RA, et al. Survival and development of neonatal rat cardiomyocytes transplanted into adult myocardium. J Mol Cell Cardiol 2002;34:107-16.

143. Musialek P, Tekieli L, Kostkiewicz M, et al. Randomized transcoronary delivery of CD34(+) cells with perfusion versus stop-flow method in patients with recent myocardial infarction: Early cardiac retention of ${ }^{99}(\mathrm{~m})$ Tc-labeled cells activity. J Nucl Cardiol 2011;18:104-16.

144. Zocchi MR, Poggi A. Lymphocyte-endothelial cell adhesion molecules at the primary tumor site in human lung and renal cell carcinomas. J Natl Cancer Inst 1993;85:246-7.

145. Woodfin A, Voisin MB, Nourshargh S. PECAM-1: a multi-functional molecule in inflammation and vascular biology. Arterioscler Thromb Vasc Biol 2007;27:2514-23.

146. Kawamoto A, Katayama M, Handa N, et al. Intramuscular transplantation of G-CSF-mobilized CD34(+) cells in patients with critical limb ischemia: a phase I/IIa, multicenter, singleblinded, dose-escalation clinical trial. Stem Cells 2009;27:285764 .

147. Kang HJ, Kim HS, Zhang SY, et al. Effects of intracoronary infusion of peripheral blood stem-cells mobilised with granulocyte-colony stimulating factor on left ventricular systolic function and restenosis after coronary stenting in myocardial infarction: the MAGIC cell randomised clinical trial. Lancet 2004;363:751-6.

148. Horwitz EM, Gordon PL, Koo WK, et al. Isolated allogeneic bone marrow-derived mesenchymal cells engraft and stimulate growth in children with osteogenesis imperfecta: Implications for cell therapy of bone. Proc Natl Acad Sci U S A 2002;99:8932-7.

149. Yoon YS, Park JS, Tkebuchava T, Luedeman C, Losordo DW. Unexpected severe calcification after transplantation of bone marrow cells in acute myocardial infarction. Circulation 2004; 109:3154-7.

150. Miyamoto K, Nishigami K, Nagaya N, et al. Unblinded pilot study of autologous transplantation of bone marrow mononuclear cells in patients with thromboangiitis obliterans. Circulation 2006; 114:2679-84. 